\title{
Anxiety Levels and Associated Factors Among Emergency Department Personnel Fighting COVID-19
}

\section{COVID-19 ile Mücadele Eden Acil Servis Çalışanlarının Anksiyete Düzeyi ve Etkileyen Faktörler}

\author{
-Ekrem Taha Sert'1, @Hüseyin Mutlu'1, @Kamil Kokulu', ๑Ayhan Sarıtaş'
}

'Department of Emergency Medicine, Aksaray University Medical School, Aksaray, Turkey

\begin{abstract}
Aim: We aimed to determine anxiety levels of the emergency department (ED) personnel working in close contact with infected patients and potential risk factors associated with this anxiety.

Materials and Methods: This cross-sectional, hospital-based study was conducted among healthcare personnel working at the ED of the tertiary healthcare hospital in question, who are directly involved in the diagnosis and treatment of COVID-19 patients. The participants were administered a questionnaire that included items on sociodemographic characteristics; items on health, social, and demographic factors considered to be related with anxiety; and the 40 items of State-Trait Anxiety Inventory (STAI).

Results: The study included 138 healthcare professionals. In total, $29.7 \%$ of the participants were female and $70.3 \%$ were male. The minimum and maximum ages of the participants were 21 and 52 years, respectively, with a median age of $33(27-40)$ years. The mean STAI-S and STAI-T scores of healthcare professionals included in the study were $45.4 \pm 10.4$ and $41.3 \pm 7.3$, respectively. The effect of women nurses and having children, on anxiety levels was found to be significantly high. Comparing the groups categorized for their compliance with COVID-19-related measures, the state anxiety scores of the "somewhat compliant" group were found to be higher. Participants with the perception that measures taken and institution's available capacity were insufficient were found to have statistically significantly higher STAI-S scores than the others $(\mathrm{p}<0.001)$.
\end{abstract}

Conclusion: Maintaining mental health of healthcare personnel during a pandemic is vital to better control contagious diseases. Thus, exclusive effort should be made to maintain mental wellbeing of healthcare professionals being exposed to COVID-19.

Keyword: COVID-19, anxiety, healthcare personnel, State-Trait Anxiety Inventory
Öz

Amaç: Bu çalışma enfekte hastalar ile yakın temasta bulunan acil servis(AS) çalışanlarında var olabilecek kaygı düzeylerini ve bunlarla ilişkili potansiyel risk faktörlerini belirlemek amacıyla yapılmıştır.

Yöntem: Bu çalışma COVID-19 hastalarının tanı, tedavileriyle doğrudan ilgilenen hastanemiz üçüncü basamak AS'de çalışan sağlık çalışanları arasında yapılmış kesitsel, hastane temelli bir çalışmadır. Araştırma kapsamında kişilere; sosyo-demografik özellikler (yaş, cinsiyet, medeni durum, çocuk sahibi olup/olmadığı, aile ile birlikte yaşama, eğitim düzeyleri, meslek durumu), kaygı ile ilişkili olduğu düşünülen sağlık, sosyal ve demografik faktörler (sigara kullanımı, kronik hastalığı olup/ olmadığı, çalışma ortamındaki tedbirlerin yeterli olup/olmadığı, çalışma ortamından memnuniyeti ve COVID-19 nedeni ile alınan tedbirlere uyumu) ve Durumluk-Sürekli Kaygı Envanteri'nden (STAI) oluşan 40 soruluk anket uygulanmıştır.

Bulgular: Çalışmaya, doğrudan COVID-19 olan veya olduğundan şüphelenilen hastaların tanı ve tedavisinin yapıldığı AS bölümdeki 138 sağlık çalışanı dahil edildi. Çalışmaya katılan bireylerin \%29.7'si ( $n=41)$ kadın, \%70.3'ü ( $n=97$ ) erkek idi. Katılımcıların yaşları en küçük 21 en büyük ise 52, medyan 33 (27-40) idi. Araştırma kapsamına alınan sağlık çalışanlarının STAI-S ortalama skoru 45.4 \pm 10.4 , STAI-T ortalama skoru $41.3 \pm 7.3$ olarak bulunmuştur. Kadın, hemşire olmak ve çocuk sahibi olmanın anksiyete düzeyi üzerindeki etkisi anlamlı olarak daha yüksek bulunmuştur. Katılımcıların durumluk/sürekli kaygı ölçek puanları COViD-19 nedeniyle alınan tedbirlere uyumlarına göre oluşturulan gruplar arasında istatistiksel olarak anlamlı derecede farklıydı $(p<0.001)$. Alınan tedbirleri ve kurumun mevcut kapasite durumunu yetersiz olarak düşünen katılımcılarda STAI-S puanları istatistiksel olarak anlamlı düzeyde daha yüksek saptandı $(p<0.001)$.

Sonuç: Salgın döneminde sağlık personelin ruh sağlığını korumak bulaşıcı hastalıkları daha iyi kontrol etmek için gereklidir. COVID-19'a maruz kalan sağlık çalışanlarının zihinsel açıdan sağlıklı kalabilmesi konusunda özel dikkat gösterilmesi gerekmektedir.

Anahtar Kelimeler: COVID-19, anksiyete, sağlık personeli, durumluk sürekli kaygı envanteri

Corresponding (illetişim): Ekrem Taha Sert, Aksaray Üniversitesi Tıp Fakültesi Dekanlığı Adana Yolu Üzeri E-90 Karayolu 7. Km Merkez, Aksaray, Türkiye

E-mail (E-posta): tahaekrem@hotmail.com

Received (Geliş Tarihi): 14.08.2020 Accepted (Kabul Tarihi): 07.09.2020 


\section{INTRODUCTION}

A novel pneumonia case caused by coronavirus disease (COVID-19), which emerged in the Wuhan City, Hubei Province of China, and rapidly spread across the world, was reported in December 2019.[1] This virus is termed as severe acute respiratory syndrome coronavirus 2 (SARS-CoV-2). Despite having a broad range of variations, COVID-19 is considered to have a higher mortality rate compared with seasonal influenza. Available evidence suggests the transmission mode of SARSCoV-2 among humans to be through close contact and droplets $^{2}$, which unavoidably puts healthcare professionals at high risk from coronavirus. Having the knowledge that COVID-19 can be transmitted between people, is associated with high morbidity, and is potentially fatal can increase perceived personal threat. ${ }^{[1-3]}$ Faced with this large-scale infectious public health issue, healthcare professionals are under physical and psychological pressure at the same time. ${ }^{[4]}$

The psychological response of healthcare professionals to the pandemic outbreak is complicated. This response may include concerns such as the risk of getting infected with the virus; transmitting the virus to family, friends, and coworkers; social isolation anxiety; vulnerability; or the feeling of losing control. [5] The concerns of healthcare professionals may further be elevated owing to factors such as the continuous increase in number of cases, intensive workload, constant risk of infection, lack of specific medications, and limited resources. ${ }^{[6]}$

Determining the anxiety levels of healthcare professionals would thus play an effective role in providing a protective approach for the group in question and for planning relevant interventions for the problems identified. The present study aimed to determine anxiety levels of the emergency department (ED) personnel working in close contact with infected patients and potential risk factors associated with this anxiety.

\section{MATERIAL AND METHOD}

This cross-sectional, hospital-based study was conducted among healthcare personnel working at the ED of the tertiary healthcare hospital in question, who are directly involved in the diagnosis and treatment of COVID-19 patients. Total number of personnel working in these units was 224. The study comprised 138 healthcare professionals. The study was approved by the local ethics committee (Ethics Committee Approval No: 2020-03/55).

Before the commencement of the study, the researchers verbally informed the participants about the study details and obtained the participants' informed consent. The participants were informed that they could opt out at any time. The questionnaire was anonymous and personal information was kept confidential. Total number of patients diagnosed with COVID-19 in the hospital was 85 , and the number of fatalities was eight as of the period the questionnaire was applied.
The participants were administered a questionnaire that included items on sociodemographic characteristics (age, gender, marital status, child status, living with family, educational status, and occupational status); items on health, social, and demographic factors considered to be related with anxiety (smoking, presence of chronic disease, adequacy of measures in the working environment, working environment satisfaction, and compliance with COVID-19-related measures); and the 40 items of State-Trait Anxiety Inventory (STAI).

The STAI consists of two subscales, each having 20 items: The state anxiety scale (STAI-S), which assesses intensity of anxiety at any given time, and the trait anxiety scale (STAI-T), which assesses general and long-term anxiety levels. Each STAl item is given a weighted score of 1-4 on a 4-point Likert scale; 10 reverse-coded items are included in STAI-S, and seven reverse-coded items are present in STAI-T. The questionnaires are evaluated by assigning scores to the selected answers that were either termed as anxiety-absent (reducing the total anxiety score) or anxiety-present (increasing the total anxiety score) within a weighted score of 1-4. A constant of 50 for STAI-S scale and 35 for STAI-T are then added to the obtained scores. The final value obtained demonstrates the individual's total anxiety score. Scores for both STAI-S-and STAI-T can vary from a minimum of 20 to a maximum of 80 . Scores of 20-35 indicates no or low anxiety, 36-41 indicated moderate anxiety, and $42-80$ indicated severe anxiety ${ }^{[7,8]}$

\section{Statistical Analysis}

Statistical analyses for the study data were performed using SPSS version 15.0 (SPSS Inc., Chicago, IL, USA). The normally distributed descriptive data were presented as Means \pm Standard Deviations, non-normally distributed data were presented as medians (interquartile range [IQR]), and categorical data were presented as n (\%). The KolmogorovSmirnov test was utilized to determine whether the data was normally distributed. Student's t-test (for normally distributed data) and the Mann-Whitney $U$ test (for non-normally distributed data) were used to compare continuous data between two groups. One-way analysis of variance and the Kruskal-Wallis test (whichever is found relevant) were used to compare continuous data between three or more groups. The post hoc Bonferroni and Tukey analyses were utilized for making subgroup comparisons. A $p$ value of $<0.05$ was considered statistically significant.

\section{RESULTS}

The present study consisted of 138 healthcare professionals working in an ED where diagnosis and treatment of confirmed or suspected COVID-19 patients were performed. In total, $29.7 \%(n=41)$ of the participants were female and $70.3 \%$ $(n=97)$ were male. The minimum and maximum ages of the participants were 21 and 52 years, respectively, with a median age of $33(27-40)$ years. 
Among the participants, 34 (24.6\%) of them were nurses, and $31(22.5 \%)$ of them were physicians. Distribution of participants regarding their sociodemographic and professional characteristics is provided in Table 1. The mean STAI-S and STAI-T scores of healthcare professionals included in the study were $45.4 \pm 10.4$ and $41.3 \pm 7.3$, respectively.

Table 1. The distribution of participants by socio-demographic and professional characteristics

\section{Variables}

\begin{tabular}{lc}
\hline Age, yr, median (IQR) & $33(27-40)$ \\
\hline Gender, $n(\%)$ & \\
Male & $97(70.3 \%)$ \\
Female & $41(29.7 \%)$ \\
\hline Marital status $n$ (\%) & \\
Married & $89(64.5 \%)$ \\
Unmarried & $49(35.5 \%)$ \\
\hline Child Status, $n$ (\%) & \\
Yes & $82(59.4 \%)$ \\
No & $56(40.6 \%)$ \\
\hline Living with the family & \\
Yes & $101(73.2 \%)$ \\
No & $37(26.8 \%)$ \\
\hline Occupation & \\
Physician & $31(22.5 \%)$ \\
Nurse & $34(24.6 \%)$ \\
Health officer & $12(8.7 \%)$ \\
Emergency medical technician & $4(2.9 \%)$ \\
Medical secretary & $11(8.0 \%)$ \\
Security & $28(20.3 \%)$ \\
Radiology technician & $7(5.1 \%)$ \\
Cleaning staff & $11(8.0 \%)$ \\
\hline Smoking & \\
Never used & $62(44.9 \%)$ \\
Used and left & $20(14.5 \%)$ \\
Actively using & $56(40.6 \%)$ \\
\hline Chronic Disease & \\
Yes & $18(13.0 \%)$ \\
\hline No & \\
\hline
\end{tabular}

The analysis results indicated that women had significantly higher levels of anxiety (STAI-S $=50.02 \pm 10.32$, STAI-T $=44.88 \pm 6.15)$ than men $(p<0.001)$. STAI-S scores of the 18-32 age groups were significantly higher than other age groups, while there was no statistically significant difference in the mean STAI-T scores $(p>0.13)$. The effect of having children on anxiety levels was found to be significantly high (STAI-S $p=0.04$, STAI-T $p=0.03$ ). The relationship between anxiety scores and sociodemographic characteristics is provided in

\section{Table 2.}

Comparing the groups categorized for their compliance with COVID-19-related measures, a statistically significantly difference was observed in STAI scores of participants ( $p$ $<0.001$ ). The Tukey post hoc subgroup analysis revealed that such a difference resulted from the difference in the mean anxiety scale scores between the "somewhat compliant" group and the "completely compliant" group $(5.87 ; 95 \%$ Confidence Interval 1.59-10.16) $(p=0.004)$ (Table 3).

Participants with the perception that measures taken and institution's available capacity were insufficient were found to have statistically significantly higher STAI-S scores than the others ( $p<0.001$ ) (Table 4). No significant difference was observed in STAI-T scores among participants who believed that the medical equipment was insufficient $(p=0.17)$.

Table 4. Comparison of anxiety scores of the participants with the perception that measures taken and institution's available capacity

\begin{tabular}{|c|c|c|c|c|}
\hline & STAI-S score & p-value & STAI-T score & p-value \\
\hline \multicolumn{5}{|c|}{ Measures taken } \\
\hline Sufficient & $42.03 \pm 9.88$ & \multirow{2}{*}{$<0.001^{*}$} & $40(35-45.25)$ & \multirow{2}{*}{0.0039} \\
\hline İnsufficient & $49.68 \pm 9.39$ & & $43.5(39.5-47)$ & \\
\hline \multicolumn{5}{|c|}{ Capacity of the institution } \\
\hline Sufficient & $41.93 \pm 9.04$ & \multirow{2}{*}{$<0.001^{*}$} & $39.63 \pm 6.63$ & \multirow{2}{*}{$<0.001^{*}$} \\
\hline İnsufficient & $50.69 \pm 10.09$ & & $44.19 \pm 7.21$ & \\
\hline \multicolumn{5}{|c|}{ Medical equipment } \\
\hline Sufficient & $42.43 \pm 9.69$ & \multirow{2}{*}{$<0.001^{*}$} & $40.68 \pm 7.35$ & \multirow{2}{*}{$0.17^{*}$} \\
\hline İnsufficient & $49.27 \pm 10.0$ & & $42.39 \pm 6.91$ & \\
\hline
\end{tabular}

Table 3. Relationship between the anxiety scale scores and the groups categorized for their compliance with COVID-19-related measures

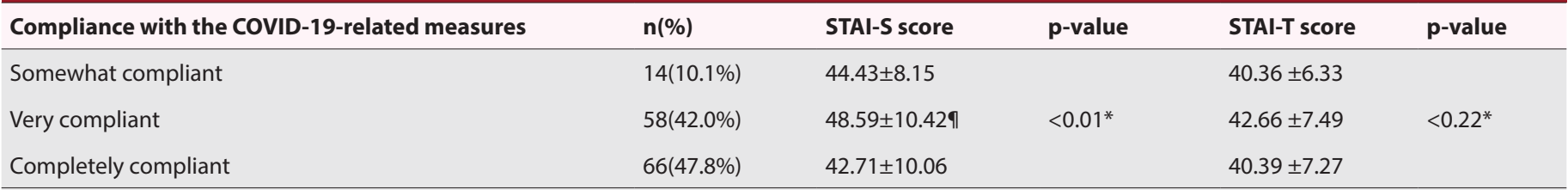

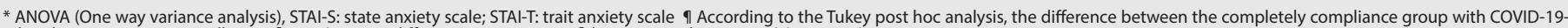
related measures is statistically significant. (average difference:5.87; $95 \%$ confidence interval $1.59-10.16)(p=0.004)$ 
Table 2. Relationship between anxiety scores and socio-demographic characteristics

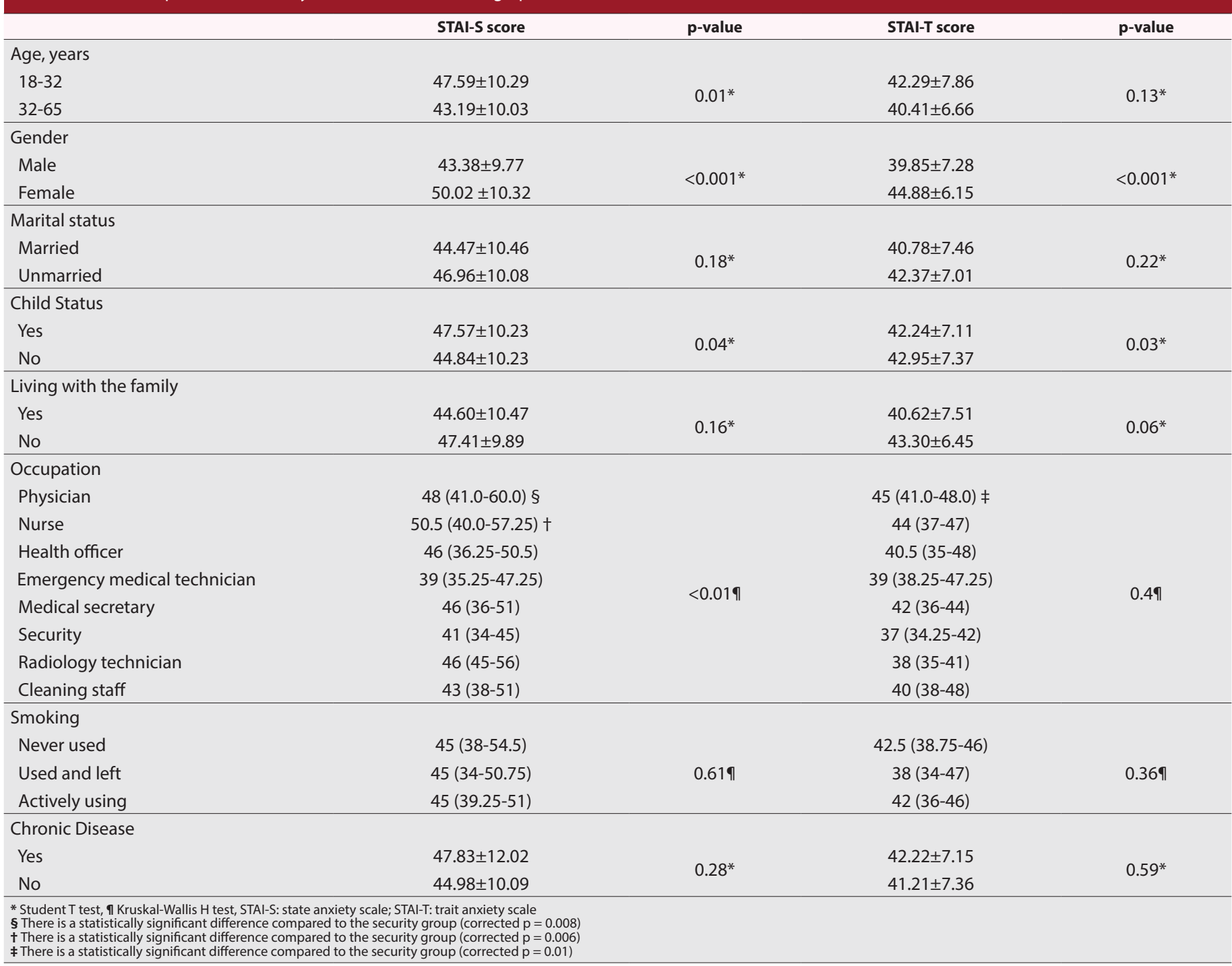

\section{DISCUSSION}

The present study suggests that the state and trait anxiety levels varied by age, gender, profession, child status, compliance with COVID-19-related measures, and the institution's available capacity and sufficiency. It was further observed that the outbreak elevated individuals' state and trait anxiety levels (STAI-S score: $45.4 \pm 10.4$, STAI-T score: $41.3 \pm 7.3$ ). During the data collection stage of the study, the number of people who lost their lives because of COVID-19 kept increasing, as declared by the Ministry of Health through daily official announcements. Such an increase in the number of fatalities might have changed the perceptions of individuals. Anxiety levels of healthcare professionals might experience a further increase owing to the increased number of cases.

Previous research revealed an increase in healthcare professionals' anxiety levels during times of pandemics. ${ }^{\left[{ }^{[9]}\right.} \mathrm{A}$ study conducted in Hong Kong during the SARS outbreak concluded that psychological reactions such as stress, helplessness, and post-traumatic disorders were found to be common among individuals during the related period. ${ }^{[10]}$ Another study assessing the adverse psychological effects of the SARS outbreak reported healthcare professionals to experience elevated levels of stress, anxiety, and depression that in turn might have long-term psychological effects. ${ }^{[11]}$ Healthcare professionals directly involved in the diagnosis, treatment, and care of COVID-19 patients were observed to develop mental health disorders such as fear, mood disorders, sleep disorders, psychological adaptation problems, depression, and anxiety because of being in close contact with infected patients. ${ }^{[12]}$ Though similar results were reported by various studies, the results vary depending on the type of pandemic, the rate of contagiousness, and the mortality rate. The high levels of state and trait anxiety scores obtained in the present study are consistent with the literature. 
Previous studies have reported old age to be a significant risk factor for COVID-19 mortality. ${ }^{[13,14]}$ In this study, STAI-S scores of the 18-32 age group were significantly higher than 32-65 age group. Although old age is reported as a high-risk group, it may seem contradictory that younger participants have a higher anxiety score. Healthcare professionals are a high risk group due to constant exposure to COVID-19 patients. The reports from China and other countries indicate a high rate of infection in the healthcare professionals. The high rate of infection in the healthcare professionals might have changed the perceptions of individuals. Anxiety levels of healthcare professionals might experience a further increase.

Literature research on pandemics noted gender differences in terms of perceived risk. Former studies on pandemics revealed that females perceived diseases to be more contagious and fatal and that they possessed a higher level of anxiety compared with males. ${ }^{[15]} \mathrm{A}$ study by Raude et al. ${ }^{[16]}$ suggested the existence of gender differences in terms of perceived risk; the study was conducted during the H1N1 outbreak and demonstrated that the perceived severity of disease and the fear of disease were greater among female participants. Another study conducted during the COVID-19 pandemic demonstrated that the female gender was associated with severe depression and anxiety. ${ }^{[17]}$ The present study revealed that anxiety levels of females were significantly higher than that of males. This finding can be considered to be in line with the findings of a limited number of studies on COVID-19 and other outbreaks.

About one-fourth of the female participants included in the present study were nurses. The findings obtained suggested that nurses had higher anxiety levels than other occupational groups. Nurses directly involved in the treatment of COVID-19 patients on the front line are probably exposed to the highest risk of infection owing to their close and frequent contact with the patients, along with their extensive working hours. ${ }^{[18]}$ A study conducted during the SARS outbreak among ED healthcare professionals reported nurses to experience elevated psychological difficulties compared with the physicians (5). Nurses treating SARS patients were reported to have both physical and psychological difficulties. ${ }^{[19,20]}$ Exclusive attention shall thus be paid to the mental well-being of the females and nurses treating COVID-19 patients.

Healthcare professionals directly engaged in the diagnosis, treatment, and care of COVID-19 patients on the front line work under intense stress. Continuous and prolonged stress causes anxiety, which in turn affects the physical, mental, and social health of individuals. ${ }^{[21]}$ Former studies indicated high levels of depression, anxiety, insomnia, and distress disorders among healthcare professionals who were fighting against the COVID-19 pandemic. ${ }^{[17]}$ It should in the meantime be noted that anxiety levels of healthcare professionals increased because of concerns related to transmitting the virus to family and other significant ones, uncertainties regarding crisis management, conflicts in roles, frequent changes in strategy, and uncertainty in general. The present study demonstrated that healthcare professionals with children had higher state and trait anxiety levels than those who did not. Based on their compliance with the measures taken for COVID-19, the state anxiety scores of the "somewhat compliant" group were found to be higher compared with other groups. It was further established that healthcare personnel were concerned about a shortage of protective equipment and a sense of inadequacy when faced with critical patients.

The small sample size of the present study was its most significant limitation, as its aim of determining perceptions regarding a pandemic affecting the whole world was considered. Further studies including a greater number of health institutions shall therefore be performed.

\section{CONCLUSION}

To conclude, protection of healthcare professionals is a crucial component of public health measures related with the COVID-19 pandemic. Maintaining mental health of healthcare personnel during a pandemic is vital to better control contagious diseases. Thus, exclusive effort should be made to maintain mental well-being of healthcare professionals being exposed to COVID-19. It is believed that the anxiety levels of healthcare professionals could be alleviated by planning and implementing specific interventions aimed at controlling sources of stress such as reducing working hours and rotations, supplying adequate physical and medical equipment at health institutions, and providing psychological assistance.

\section{ETHICAL DECLARATIONS}

Ethics Comittee Approval: Aksaray University School of Medicine, Aksaray Education and Research Hospital Scientific Research Evaluation Committee approval was obtained for this study (approval number: 2020-03/55).

Conflict of Interest Statement: No conflict of interest was declared by the authors.

Financial Disclosure: The authors declared that this study has received no financial support.

\section{REFERENCES}

1. Li Q, Guan X, Wu P, et al. Early transmission dynamics in Wuhan, China, of novel coronavirus-infected pneumonia. N Engl J Med 2020;382(13):11991207.

2. World Health Organization (WHO) Emergency Committee. Statement on the second meeting of the International Health Regulations (2005) Emergency Committee regarding the outbreak of novel coronavirus (2019-nCoV). Geneva: WHO; 30 January 2020. Available from: https:// www.who.int/ news-room/detail/30-01-2020-statement-on-thesecondmeeting - of - the-international - health-regulations- (2005) emergency-committee regarding - the - outbreak - of-novelcoronavirus(2019-ncov).

3. Wang W, Tang J, Wei F. Updated understanding of the outbreak of 2019 novel coronavirus (2019-nCoV) in Wuhan, China. J Med Virol. 2020;92(4):441-447. 
4. Wu P, Fang Y, Guan Z, et al. The psychological impact of the SARS epidemic on hospital employees in China: exposure, risk perception, and altruistic acceptance of risk. Can J Psychiatry 2009;54(5):302-311.

5. Wong TW, Yau JK, Chan CL, et al. The psychological impact of severe acute respiratory syndrome outbreak on healthcare workers in emergency departments and how they cope. Eur J Emerg Med. 2005;12(1):13-18.

6. Chan-Yeung M. Severe acute respiratory syndrome (SARS) and healthcare workers. Int J Occup Environ Health 2004;10(4):421-7.

7. Öner N, Le Compte A. Süreksiz durumluk/sürekli kaygı envanteri el kitabı. 1. Baskı. İstanbul: Boğaziçi Üniversitesi Yayını, 1983; 1-26.

8. Spielberger CD, Gorsuch RL, Lushene RE. Test manual for the State Trait Anxiety Inventory. 1 st ed. California: Consulting Psychologists Press, 1970.

9. Taylor MR, Agho KE, Stevens GJ, Raphael B. Factors influencing psychological distress during a disease epidemic: data from Australia's first outbreak of equine influenza. BMC Public Health 2008; 8:347.

10. Lau JT, Yang X, Pang E, Tsui HY, Wong E, Wing YK. SARS-related perceptions in Hong Kong. Emerg Infect Dis 2005;11(3):417-424.

11. Lee AM, Wong JG, McAlonan GM, et al. Stress and psychological distress among SARS survivors 1 year after the outbreak. Can J Psychiatry 2007:52(4):233-40.

12. Kang L, Li Y, Hu S, et al. The mental health of medical workers in Wuhan, China dealing with the 2019 novel coronavirus. Lancet Psychiatry 2020;7(3):e14.

13. Leung C. Risk factors for predicting mortality in elderly patients with COVID-19: a review of clinical data in China. Mech Ageing Dev 2020;188:111255.

14. Zhou F, Yu T, Du R, et al. Clinical course and risk factors for mortality of adult inpatients with COVID-19 in Wuhan, China: a retrospective cohort study. Lancet 2020;395:1054-1062.

15. Leung GM, Ho LM, Chan SK, et al. Longitudinal assessment of community psychobehavioral responses during and after the 2003 outbreak of severe acute respiratory syndrome in Hong Kong. Clin Infect Dis 2005;40(12):1713-20.

16. Raude J, Setbon M. Lay perceptions of the pandemic influenza threat. Eur J Epidemiol 2009;24(7):339-42.

17. Lai J, Ma S, Wang Y, et al. Factors Associated With Mental Health Outcomes Among Health Care Workers Exposed to Coronavirus Disease 2019. JAMA Netw Open 2020;3(3):e203976.

18. Shih FJ, Gau ML, Kao CC, et al. Dying and caring on the edge: Taiwan's surviving nurses' reflections on taking care of patients with severe acute respiratory syndrome. Appl Nurs Res. 2007;20(4):171-80.

19. Chan S. Nurses fighting against severe acute respiratory syndrome (SARS) in Hong Kong. J Nurs Scholarsh. 2003;35(3):209.

20. Tzeng HM. Fighting the SARS epidemic in Taiwan: a nursing perspective. J Nurs Adm 2003;33(11):565-567.

21. Sabuncu, N, Alpar ŞE, Özdilli K, et al. Hemşirelikte Temel Kavramlar- Stres. Sabuncu N. Ed. Hemşirelik Bakımında İlke ve Uygulamalar, Ankara: Alter Yayıncılık. 2008. ss: 20-22. 